\title{
Livelihood Security of Small and Marginal Farmers in Ambala Division of Haryana State, India
}

\author{
Saurabh Arya ${ }^{1 *}$, Asha Batra ${ }^{1}$ and Arpit Arya ${ }^{2^{*}}$ \\ ${ }^{1}$ Department of Extension Education and Communication Management, Chaudhary Charan \\ Singh, Haryana Agricultural University Hisar-125004, India \\ ${ }^{2}$ Department of Foods and Nutrition, Government Home Science College, Chandigarh \\ 160010, India
}

*Corresponding author

\begin{tabular}{l} 
Ke y w or d s \\
$\begin{array}{l}\text { Livelihood, } \\
\text { Security, Food } \\
\text { security, Small and } \\
\text { marginal farmers, } \\
\text { Rural }\end{array}$ \\
\hline Article Info \\
\hline $\begin{array}{l}\text { Accepted: } \\
\text { xx September } 2019 \\
\text { Available Online: } \\
\text { xx October } 2019\end{array}$ \\
\hline
\end{tabular}

\section{A B S T R A C T}

The present investigation "Livelihood securities of small and marginal farm families of Ambala division of Haryana state" was conducted in Ambala division of Haryana state. Two districts from Ambala division i.e. Ambala and Yamunanagar were selected randomly. One block from each district viz. Sadhora block from Ambala and Nareingarh block from Yamunanagar district were selected randomly. From selected two blocks Sadhora and Nareingarh four villages (two from each block) Rajpur and Nashera from Sadhora, Sain Majra and Badi Ujjal from Nareingarh were selected randomly. Thus a total of 300 respondents were selected randomly. Statistical tools frequency percentages, weighted mean score and ranking were applied for data analysis. In the present study livelihood security was assessed by developing media on identified aspect of livelihood security. Food security was concerned majority of the respondents had sources of food from their own farm production cum market, had two meals lunch and dinner/ day, less than forty per cent of the respondents rarely consumed fruit. Most of the respondents had enough food to eat but not quality. Most of the respondents in both the districts had enough consumption of cereals, milk and milk products. Consumptions of pulses, vegetables and fruits were very less. Regarding economic security less than half of the farm families had household annual income between 1 to 2 lacks annually. More than seventy five per cent of the respondents possessed land upto Rs. 10 lakh as a productive asset. Eighty five per cent of the respondents had gold upto 50 gram as unproductive assets. Possession of value of residential property between 2-4 lakh by more than sixty per cent of household. Fifty per cent of respondents were somewhat dissatisfied with their current financial conditions.

\section{Introduction}

Indian agribusiness is outstanding for its multi-functionalities of giving work, business, sustenance, nutrition and environmental protections. Agriculture and allied activities contribute about 14.2 percent to the total national output and the development pace of agribusiness is around 6.6 percent (2015-16). Indian farming utilizes 58.0 percent of the 
absolute work power and it is the significant source of destitution alleviation, strengthening of the agrarian culture and it is the foundation of improvement for India (Chand et al., 2011). India with a land an area spreading in excess of 329 million hectares is provided with complex assorted variety of environment, soils, vegetation offering both a gift and a test for horticultural advancement. The quality and richness of the nation asset endowments is constantly threatened by the huge population and increasing population density and corresponding demand for arable lands and ensuring food security. The green revolution in wheat and rice, white revolution in milk, yellow revolution in oilseed and the "blue revolution" in fisheries have augmented the food basket of the country. Be that as it may, numerous technological difficulties remain. In the first place, in spite of the shrinking share $(23 \%)$ of the agricultural sector in the economy, most of the labour force (about $60 \%$ ) keeps on relying upon agribusiness. Around $75 \%$ of India's needy individuals with low buying power live in rural area and about $60 \%$ of the cultivated area is under rainfed farming (Gautam et al., 2007). A major farming community of India comes under small and marginal cultivating community, where the size of land holding is low to accomplish the benchmarks of occupation. Farming is the pillar of the Indian economy, as it establishes the foundation of the provincial occupation security framework. In India little homesteads have been the pillar for sustenance security and work in India. Regardless of their essentialness in giving nourishment security, family work business and economy in the board and high efficiency per section of land, little ranches face a couple of difficulties especially in the wake of globalization and WTO administration (Maxwell and Frankenberger, 1992). Rural people depend on more than one resource and more than one activity for earning their livelihoods. A poor household will raise food security enhancing crops on a small piece of land, rear livestock animals, and migrate to cities as unskilled labour. A landless family may work as farm labour and construction labour, and may also make bidis or agarbattis etc. Another family may rent in land for agriculture and regularly move to Punjab to fill in as homestead work or to Gujarat to chip away at block furnaces, etc. Around seventy five percent of the world's farmers develop little plots of land; India is the place that is known for small and marginal farmers comprising more than 80 percent. As indicated by agricultural enumeration 2011, the little and minor property taken together (underneath 2.00 ha.) establish 84.97 percent in 2010-11 against 83.29 percent in 2005-06. Small and land less farmers are the individuals for whom cultivating is a noteworthy job action, they feed the entire nation however are as yet starving. They face insecurity of tenure, threats of land alienation, growing forces of urbanization and industrialization and constraints in the process of cultivations in the growing agricultural value chain. They owned tiny parts of lands as mostly unirrigated, fragmented which can be termed as unviable economical land holdings as it is noticed that the zeal and enthusiasm among the farmers are reducing as they don't want to be a farmer if given an opportunity elsewhere but unfotunately there is no scope to flourish in other sectors because they lack all types of resources whether land, capital and skills which is highly demanded in other sectors of the economy. Agriculture plays a pivotal role in the Indian economy. Small holdings agriculture is important for raising agriculture growth, food security and livelihoods in India. Therefore, the future of sustainable agriculture growth and food security in India depends on the performance of small and marginal farmers. Agricultural Census data shows that there were about 121 million agricultural holdings in India in 2000-01. Of which 99 million were small and marginal farmers. Small and marginal farmers account for more 
than $80 \%$ of total farm hectares, but their share in operated area is around $44 \%$. Despite the belief that employment leads to women's empowerment, there is very little research that empirically tests this relationship. It is against this background the present study has been undertaken with the objective to explore livelihood capabilities of farm families in the Ambala division of Haryana state.

\section{Materials and Methods}

The study was conducted in Haryana state. Haryana state has been divided into four division- Ambala, Hisar, Rohtak and Gurgoun divisions. The present study was conducted in Ambala division which comprises of five district viz., Ambala, Kaithal, Kurukshetra, Panchkula and Yamunanagar out of five districts, two districts from Ambala division that is Ambala and Yamunanagar were selected randomly. One block from each district namly sadhora from Yamunanagar district and Nargard from Ambal district were selected randomly. Two villages' that is Rajpur and nashera from sadhora block and badi ujjal and sain majra were selected from nareingarh block randomly. From the selected villages a sample of 75 small and marginal farm families were drawn randomly. Thus a total of 300 respondents were selected randomly as a sample for the present study. Data were collected by the investigator with help of pre structure interview schedule. Frequency, percentage, weighted mean score, overall mean score, co-relation coefficient were applied to draw the inferences from the collected data.

\section{Results and Discussion}

Food security is access of enough food to all individuals of family to lead active and healthy life. It incorporates sources of food for sampled households, number of meals the household normally had every day, frequency of fruits and vegetables intake etc. The findings of present study showed that more than fifty per cent farm families had their source of food from their own farm production as well as from market. The findings of AMEU (2016) did not match with the findings of present study. AMEU (2016) revealed that respondents relied in super market for purchase of food. The findings of Jodha (2018) were in line with the findings of present study (Table 1).

The study further indicates that 53.33 per cent of respondents consume vegetable daily. Similar findings were reported by Adekoya (2009) that vegetable being most affordable food item and easily accessible consumed by 90.00 per cent of respondents. Similar findings were reported by Jodha (2018) that it was consumed by 54.33 per cent of the households. To meet food security and nutritional requirements of the family, food intake must be from different food groups. The study further showed that cent per cent of the household had consumption of cereals in both of the selected districts. Shakti et al., (2013), Rani (2015) and Jodha (2018) observed that daily consumption of cereals food group was maximum as compared to other food groups. Second rank was given by selected household to the consumption of milk and milk products in the present study. Rani (2015) reported that buffalos milk and butter milk was consumed daily by 41.00 per cent and 3.00 per cent of family. Jodha (2018) also reported that more than half of the farm families consume milk and milk products daily in Gurgaon division of Haryana state. Study further reported that consumption of vegetables, pulses and fruits ranked as III, IV and V. Sati and Dahiya (2012) reported that due to the lack of awareness of importance of G.L.V (green leafy vegetables), respondents consume less G.L.V. Findings of Hens (2014) and report of AMFU (2016) are in an agreement with the findings of present study. 
BMI is a relative measure of whether an individual weight is at a healthy level for their height. This study indicates that BMI of children (0-5 years) in both the districts (Ambala and Yamunanagar) fall in the category of normal weight $(59.52 \%)$ followed by underweight (33.33\%), overweight (8.33 $\%$ ) and obese $(1.90 \%)$, respectively (Table 2$)$. Neha (2011) detected underweight children (32.50\%) among school children of Hisar district of Haryana State.

Similar findings were reported by Kumar et al., (2014) who reported that 63.97 percent children were malnourished. This study further revealed that adult women $(46.43 \%)$ were categorized under medium BMI range (18.5-24.9), 30.48 percent adult women categorized under low BMI range (18.5 or less), 19.37 percent adult women categorized in high BMI (25 to 29.9) and only 3.70 percent adult women fall in the category of obese (30 and above). Low BMI is due to low emphasis on fruits, pulses and vegetables. They give emphasis on consumption of cereals only. The present study is in accordance with Rout (2009) who reported that in Orissa state almost half of the rural women $(48.60 \%)$ were underweight and 3.30 percent were low weight.

Economic security includes household annual income, possession of productive, unproductive assets, value of residential property, satisfied or dissatisfied with current financial condition and household currently in debt or not (Table 3).

The result of the study reveals that little less than half of the respondents $(46.33 \%)$ were having their household annual income between 1 to 2 lakh followed by more than 2 to 3 lakh (25.67\%), below 1 lakh (19.33\%), 3 to 4 lakh $(7.00 \%)$ and above 4 lakh only (1.67\%) respectively. Similar findings were reported by Yadav (2016) who reported that
38.50 per cent farm families had income in between 1 to 2 lakh annually. As far as the possession of productive assets in the form of livestock and land was concerned the results revealed that 39.67 percent respondents had possession of productive assets as livestock worth more than Rs.60,000 to 90,000 followed by more than Rs30,000 to 60,000 (38.00\%), upto Rs30,000 (17.67 \%) and more than Rs90,000 to $1,20,000$ (4.67\%) respectively. The present study are in accordance with Bal (2015) who reported that value of the productive assets (livestock) pointed to satisfactory scores 3.21 for farm category. It was also found that more than seventy five per cent of the respondents $(78.67 \%)$ had possession of land worth Rs upto10 lakh followed by Rs 10-15 lakhs (18.00\%) and more than 15-20 lakh (3.33\%) respectively. It was also found that in both the districts more than eighty five per cent of the respondents $(85.33 \%)$ had possession of unproductive assets as gold, 60.0 percent respondents had possession of residential property worth Rs. 2 to 4 lakh. The present study is in accordance with Bal (2015) who reported that value of productive assets is satisfactory for farm category.

The basic amenities such as access to safe water, good housing condition, source of lighting except electricity, source of cooking fuel, latrine facility and road facility are the important pointers that considerably impact the health of the family and its socio economic condition. It was found that that most of farm families $(66.33 \%)$ were having water availability for drinking and cooking through tank/ tubewell followed by water from hand pumps/well (16.33\%), community hand pumps $(13.67 \%)$ and water treatment $(3.67 \%)$ respectively. The results of this study are in accordance with Singh (2017) who reported that the utility of tube well/bore well had increased from 5.00 per cent to 21.50 percent of the total households of the Panghal village. 
Table.1 Food security of farm families

\begin{tabular}{|c|c|c|c|c|c|c|c|}
\hline \multirow[t]{2}{*}{$\begin{array}{l}\text { Sr. } \\
\text { No. }\end{array}$} & \multirow[t]{2}{*}{ Variables } & \multicolumn{2}{|c|}{$\begin{array}{c}\text { Ambala } \\
(\mathbf{n}=150)\end{array}$} & \multicolumn{2}{|c|}{$\begin{array}{c}\text { Yamunanagar } \\
(\mathbf{n}=150)\end{array}$} & \multicolumn{2}{|c|}{$\begin{array}{c}\text { Total } \\
(\mathbf{N}=300)\end{array}$} \\
\hline & & f & $\%$ & $\mathbf{f}$ & $\%$ & f & $\%$ \\
\hline 1. & \multicolumn{7}{|c|}{ Sources of food } \\
\hline & Own farm production & 37 & 24.67 & 48 & 32.00 & 85 & 28.33 \\
\hline & Own farm production +market & 84 & 56.00 & 91 & 60.67 & 175 & 58.33 \\
\hline & Market only & 29 & 19.33 & 11 & 7.33 & 40 & 13.33 \\
\hline & Exchange work for food & - & - & - & - & - & - \\
\hline & Food assistance & - & -- & - & - & - & - \\
\hline \multirow[t]{6}{*}{2.} & \multicolumn{7}{|c|}{ Number of meals the household normally has per day } \\
\hline & Breakfast-lunch-dinner & 21 & 14.00 & 39 & 26.00 & 60 & 20.00 \\
\hline & Breakfast and dinner & 34 & 22.67 & 28 & 18.67 & 62 & 20.67 \\
\hline & Lunch and dinner & 95 & 63.33 & 83 & 55.33 & 178 & 59.33 \\
\hline & Breakfast and lunch & - & - & - & - & - & - \\
\hline & Only breakfast & - & - & - & - & - & - \\
\hline \multirow[t]{6}{*}{3} & \multicolumn{7}{|c|}{ Frequency of fruits intake } \\
\hline & Daily & 7 & 4.67 & 11 & 7.33 & 18 & 6.00 \\
\hline & Twice or thrice a week & 20 & 13.33 & 18 & 12.00 & 38 & 12.67 \\
\hline & Once in a week & 22 & 14.67 & 34 & 22.67 & 56 & 18.67 \\
\hline & Once in a month & 38 & 25.33 & 41 & 27.33 & 79 & 26.33 \\
\hline & Rarely & 63 & 42.00 & 46 & 30.67 & 109 & 36.33 \\
\hline \multirow[t]{6}{*}{4.} & \multicolumn{7}{|c|}{ Frequency of vegetables intake } \\
\hline & Daily & 78 & 52.00 & 82 & 54.67 & 160 & 53.33 \\
\hline & Twice or thrice a week & 41 & 27.33 & 43 & 28.67 & 84 & 28.00 \\
\hline & Once in a week & 31 & 20.67 & 25 & 16.67 & 56 & 18.67 \\
\hline & Once in a month & - & - & - & - & - & - \\
\hline & Rarely & - & - & - & - & - & - \\
\hline \multirow[t]{6}{*}{5.} & \multicolumn{7}{|c|}{$\begin{array}{l}\text { During last } 12 \text { months, ate fewer meals, or smaller portions than usual because there } \\
\text { was not enough food }\end{array}$} \\
\hline & Never & 86 & 57.33 & 116 & 77.33 & 202 & 67.33 \\
\hline & Once or twice/annum & 51 & 34.00 & 34 & 22.67 & 85 & 28.33 \\
\hline & Once or twice/month & 13 & 8.67 & - & - & 13 & 4.33 \\
\hline & Once or twice/week & - & - & - & - & - & - \\
\hline & Every day & - & - & - & - & - & - \\
\hline \multirow[t]{6}{*}{6.} & \multicolumn{7}{|c|}{ Amount and quality of food eaten in your household in the last 12 months } \\
\hline & Enough food to eat & 81 & 54.00 & 87 & 58.00 & 168 & 56.00 \\
\hline & Enough quantity but not quality & 63 & 42.00 & 63 & 42.00 & 126 & 42.00 \\
\hline & Sometimes not enough & 6 & 4.00 & - & - & 6 & 2.00 \\
\hline & Often not enough to eat & - & - & - & - & - & - \\
\hline & Always not enough & - & - & - & - & - & - \\
\hline
\end{tabular}


Table.2 BMI of children (up to 5 years), adult women

\begin{tabular}{|c|c|c|c|c|c|c|c|}
\hline \multirow[t]{2}{*}{$\begin{array}{l}\text { Sr. } \\
\text { No. }\end{array}$} & \multirow[t]{2}{*}{ Variables } & \multicolumn{2}{|c|}{$\begin{array}{l}\text { Ambala } \\
(\mathbf{n}=150)\end{array}$} & \multicolumn{2}{|c|}{$\begin{array}{c}\text { Yamunanagar } \\
(\mathbf{n}=\mathbf{1 5 0})\end{array}$} & \multicolumn{2}{|c|}{$\begin{array}{c}\text { Total } \\
(\mathbf{N}=\mathbf{3 0 0})\end{array}$} \\
\hline & & $\mathrm{f}$ & $\%$ & $\mathrm{f}$ & $\%$ & f & $\%$ \\
\hline \multirow[t]{5}{*}{1} & Children (upto 5 years) & \multicolumn{2}{|c|}{$\mathrm{n}=43$} & \multicolumn{2}{|c|}{$\mathrm{n}=41$} & \multicolumn{2}{|c|}{$\mathrm{n}=84$} \\
\hline & Low BMI (underweight) & 11 & 25.6 & 17 & 41.46 & 28 & 33.33 \\
\hline & Medium BMI (Normal Weight) & 29 & 67.44 & 21 & 51.21 & 50 & 59.52 \\
\hline & High BMI (overweight) & 3 & 6.9 & 4 & 9.7 & 7 & 8.33 \\
\hline & Very High BMI (Obese) & - & - & 1 & 2.4 & 1 & 1.19 \\
\hline \multirow[t]{5}{*}{2.} & ADULTS WOMEN (18-40 years) & \multicolumn{2}{|c|}{$\mathrm{n}=182$} & \multicolumn{2}{|c|}{$\mathrm{n}=169$} & \multicolumn{2}{|c|}{$\mathrm{n}=351$} \\
\hline & Low BMI (underweight) & 58 & 31.86 & 49 & 28.99 & 107 & 30.48 \\
\hline & Medium BMI (Normal Weight) & 78 & 42.85 & 85 & 50.29 & 163 & 46.43 \\
\hline & High BMI (overweight) & 41 & 22.52 & 27 & 15.97 & 68 & 19.37 \\
\hline & Very High BMI (Obese) & 05 & 2.74 & 8 & 4.73 & 13 & 3.7 \\
\hline
\end{tabular}

Table.3 Economic security of farm families

\begin{tabular}{|c|c|c|c|c|c|c|c|}
\hline \multirow[t]{2}{*}{$\begin{array}{l}\text { Sr. } \\
\text { No. }\end{array}$} & \multirow[t]{2}{*}{ Variables } & \multicolumn{2}{|c|}{$\begin{array}{l}\text { Ambala } \\
(n=150)\end{array}$} & \multicolumn{2}{|c|}{$\begin{array}{c}\text { Yamunanagar } \\
(n=150)\end{array}$} & \multicolumn{2}{|c|}{ Total } \\
\hline & & f & $\%$ & f & $\%$ & f & $\%$ \\
\hline \multirow[t]{6}{*}{1.} & \multicolumn{7}{|c|}{ Household annual income } \\
\hline & Below 1 lakh & 25 & 16.67 & 33 & 22.00 & 58 & 19.33 \\
\hline & 1 to 2 lakh & 76 & 50.67 & 63 & 42.00 & 139 & 46.33 \\
\hline & 2 to 3 lakh & 37 & 24.66 & 40 & 26.67 & 77 & 25.67 \\
\hline & 3 to 4 lakh & 12 & 8.00 & 9 & 6.00 & 21 & 7.00 \\
\hline & Above 4 lakh & - & - & 5 & 3.33 & 5 & 1.67 \\
\hline \multicolumn{8}{|c|}{ Value of productive assets } \\
\hline \multirow[t]{6}{*}{ a) } & \multicolumn{7}{|c|}{ Livestock } \\
\hline & Upto 30,000 & 27 & 18.00 & 26 & 17.33 & 53 & 17.67 \\
\hline & $>30,000-60,000$ & 67 & 44.67 & 47 & 31.33 & 114 & 38.00 \\
\hline & $>60,000-90,000$ & 52 & 34.67 & 67 & 44.67 & 119 & 39.67 \\
\hline & $>90,000-1,20,000$ & 4 & 2.67 & 10 & 6.67 & 14 & 4.67 \\
\hline & Above $1,20,000$ & - & - & - & - & - & - \\
\hline \multirow[t]{6}{*}{ b) } & \multicolumn{7}{|c|}{ Land } \\
\hline & Upto 10 lakh & 112 & 74.67 & 124 & 82.67 & 236 & 78.67 \\
\hline & $>10-15$ lakh & 38 & 25.33 & 16 & 10.67 & 54 & 18.00 \\
\hline & $>15-20$ lakh & - & & 10 & 6.67 & 10 & 3.33 \\
\hline & $>20-25$ lakh & - & - & - & - & - & - \\
\hline & Above 25 lakh & - & - & - & - & - & - \\
\hline 3. & \multicolumn{7}{|c|}{ Value of unproductive assets } \\
\hline \multirow[t]{6}{*}{ a) } & \multicolumn{7}{|c|}{ Gold } \\
\hline & Upto $50 \mathrm{gm}$ & 126 & 84.00 & 130 & 86.67 & 256 & 85.33 \\
\hline & $>50-100 \mathrm{gm}$ & 19 & 12.67 & 11 & 7.33 & 30 & 10.00 \\
\hline & $>100-150 \mathrm{gm}$ & 5 & 3.33 & 9 & 6.00 & 14 & 4.67 \\
\hline & $>150-200 \mathrm{gm}$ & - & - & - & - & - & - \\
\hline & Above $201 \mathrm{gm}$ & - & - & - & - & - & - \\
\hline b) & \multicolumn{7}{|c|}{ Value of residential property } \\
\hline
\end{tabular}




\begin{tabular}{|c|c|c|c|c|c|c|c|}
\hline & Upto 2 lakh & 39 & 26.00 & 46 & 30.67 & 85 & 28.33 \\
\hline & 2-4 lakh & 93 & 62.00 & 99 & 66.00 & 192 & 64.00 \\
\hline & 4-6 lakh & 18 & 12.00 & 5 & 3.33 & 23 & 7.67 \\
\hline & 6-8 lakh & - & - & - & - & - & - \\
\hline & Above 12 lakh & - & - & - & - & - & - \\
\hline $\mathbf{4 .}$ & No & \multicolumn{2}{|c|}{ Household currently in debt } & & & \\
\hline & Yes, a little & 59 & 39.33 & 55 & 36.67 & 114 & 38.00 \\
\hline & 42 & 28.00 & 69 & 46.00 & 111 & 37.00 \\
\hline & Moderate amount & 38 & 25.33 & 21 & 14.00 & 59 & 19.67 \\
\hline & High amount & 11 & 7.33 & 5 & 3.33 & 16 & 5.33 \\
\hline & Unmanageable & - & - & - & - & - & - \\
\hline 5. Satisfied or dissatisfied with current financial condition & & \\
\hline & Satisfied & - & & - & & & \\
\hline & Somewhat satisfied & 7 & 4.67 & 21 & 14.00 & 28 & 9.33 \\
\hline & Somewhat dissatisfied & 83 & 55.33 & 67 & 44.67 & 150 & 50.00 \\
\hline & Dissatisfied & 41 & 27.33 & 52 & 34.67 & 93 & 31.00 \\
\hline & Fully dissatisfied & 19 & 12.67 & 10 & 6.66 & 29 & 9.67 \\
\hline
\end{tabular}

Table.4 Education security of farm families

\begin{tabular}{|c|c|c|c|c|c|c|c|}
\hline \multirow[t]{2}{*}{$\begin{array}{l}\text { Sr. } \\
\text { No. }\end{array}$} & \multirow[t]{2}{*}{ Variables } & \multicolumn{2}{|c|}{$\begin{array}{c}\text { Ambala } \\
(n=150)\end{array}$} & \multicolumn{2}{|c|}{$\begin{array}{c}\text { Yamunanagar } \\
(\mathbf{n}=\mathbf{1 5 0})\end{array}$} & \multicolumn{2}{|c|}{$\begin{array}{c}\text { Total } \\
(\mathbf{N}=300)\end{array}$} \\
\hline & & f & $\%$ & $\mathbf{f}$ & $\%$ & f & $\%$ \\
\hline \multirow[t]{6}{*}{1.} & \multicolumn{7}{|c|}{ Household literacy level } \\
\hline & Can read/ write & 87 & 58.00 & 109 & 72.67 & 196 & 65.33 \\
\hline & Upto primary & 136 & 90.67 & 130 & 86.67 & 266 & 88.67 \\
\hline & Upto matric & 96 & 64.00 & 103 & 68.67 & 199 & 66.33 \\
\hline & Upto graduation & 43 & 28.67 & 87 & 58.00 & 130 & 43.33 \\
\hline & Upto vocation & 16 & 10.67 & 24 & 16.00 & 40 & 13.33 \\
\hline \multirow[t]{6}{*}{2.} & \multicolumn{7}{|c|}{ Accessibility of school } \\
\hline & $0-1 \mathrm{~km}$ & 53 & 35.33 & 57 & 38.00 & 110 & 36.67 \\
\hline & $>1-2 \mathrm{~km}$ & 73 & 48.67 & 59 & 39.33 & 132 & 44.00 \\
\hline & $>2-4 \mathrm{Km}$ & 17 & 11.33 & 23 & 15.33 & 40 & 13.33 \\
\hline & $>4-6 \mathrm{~km}$ & 4 & 2.67 & 11 & 7.33 & 15 & 5.00 \\
\hline & Beyond 6 km & - & - & - & - & - & - \\
\hline \multirow[t]{6}{*}{3.} & \multicolumn{7}{|c|}{ Access of higher/ vocational education } \\
\hline & $0-1 \mathrm{~km}$ & - & - & - & - & - & - \\
\hline & $>1-2 \mathrm{~km}$ & - & - & - & - & - & - \\
\hline & $>2-4 \mathrm{Km}$ & 27 & 18.00 & 44 & 29.33 & 71 & 23.67 \\
\hline & $>4-6 \mathrm{~km}$ & 76 & 50.67 & 87 & 58.00 & 163 & 54.33 \\
\hline & Beyond $6 \mathrm{~km}$ & 47 & 31.33 & 19 & 12.67 & 66 & 22.00 \\
\hline \multirow[t]{5}{*}{4.} & \multicolumn{7}{|c|}{ Availability of educational institutes } \\
\hline & Technical education in village & 56 & 37.33 & 34 & 22.67 & 90 & 30.00 \\
\hline & Secondary school & 130 & 86.67 & 141 & 94.00 & 271 & 90.33 \\
\hline & High school & 150 & 100.00 & 150 & 100.00 & 300 & 100.00 \\
\hline & Middle school & 150 & 100.00 & 150 & 100.00 & 300 & 100.00 \\
\hline
\end{tabular}




\begin{tabular}{|c|c|c|c|c|c|c|c|c|}
\hline & Primary school & 150 & 100.00 & 150 & 100.00 & 300 & 100.00 \\
\hline & 5. & Cost of education & & & \\
\hline & Most expensive & - & - & - & - & - & - \\
\hline & Expensive & 64 & 42.67 & 30 & 20.00 & 94 & 31.33 \\
\hline & Undecided & 32 & 21.33 & 41 & 27.33 & 73 & 24.33 \\
\hline Cheap & 51 & 34.00 & 68 & 45.33 & 119 & 39.67 \\
\hline & Very Cheap & 3 & 2.00 & 11 & 7.33 & 14 & 4.67 \\
\hline
\end{tabular}

It was also observed that almost half of the respondents $(49.33 \%)$ in both the districts had kitchen in an open area and only 4.33 per cent had availability of kitchen in living room. The contrary results were reported by Bal (2015) who reported that respondents had good facility of kitchens within the premises with water source in it.

The study also reported in both the districts nearly fifty percent $(44.00 \%)$ had availability of separate shelter for the livestock in the field. The findings are in contrary with the study of Kharadi et al., (2015) who revealed that 88.33 percent of the respondents keep their animals inside the home followed by separate shelter.

It was also reported that 100 percent sample households in both the districts were electrified. In emergencies respondents were using other sources of lighting like inverter, solar lantern, candle, torch and kerosene lamp, 41.00 percent had torch, 18.00 percent had solar lantern, $17.33 \%$ kerosene lantern and 14.67 had invertors as source of lighting in emergency. A small percentage of sample households $(9.00 \%)$ had candle as source of electricity. In rural areas with regards to source of cooking fuel in both the districts majority of the sample households were using dung as a source of cooking fuel followed by wood, LPG and crop residue respectively. Similar results were reported by Census (2011) that majority of the households depends on dung, firewood followed by LPG and crop residue respectively.
It was also observed that in both the districts 43.00 percent of household accessed pit flush toilet, 24.66 percent accessed improved pit, 15.00 percent were accessing flush toilets and only 8.33 percent defecate in an open field. The present study are in accordance with swachta status report 2016 which concluded that in rural area 45.30 per cent households were having sanitary toilets. Similar results were also reported by Ramaraju (2013) that about 14.00 per cent of the households practiced open defecation in the village Vasadi in Kerala. Rural water sanitation and hygiene provision supports rural livelihood by promoting food security, health and productive activities (Census of India, 2011).

To determine the educational security of the study area five indicators for educational security were taken i.e. household literacy level, accessibility to school, accessibility to higher/ vocational education, availability of educational institutes and the cost of education (Table 4).

Education is the important tool in making individual into a human resource or a human capital. The study reveals that in Ambala and Yamunanagar district most of the household members $(90.67 \%)$ and $(86.67 \%)$ educated upto primary respectively. Similar results were also reported by Preeti (2014) who reveled that 48.00 per cent families had medium level of education status.

The results of this study are in accordance with the study of Yadav (2016) who reported that more than half of the farm families had 
medium level of education status. The study also concluded that maximum of the respondents $(44.00 \%)$ had accessibility to school in the area of more than 1 to $2 \mathrm{~km}$ followed by more than 0 to $1 \mathrm{~km}(36.67 \%)$ and more than 2 to $4 \mathrm{~km} \mathrm{(13.33 \% )}$ respectively in both the districts.

It was also reported that more than half of the respondents $(54.33 \%)$ had accessibility to higher/ vocational education in the area of more than 4 to $6 \mathrm{~km}$ followed by $2-4 \mathrm{~km}$ $(23.67 \%)$ and beyond $6 \mathrm{~km}(22.00 \%)$ respectively. The cost of the education was also perceived expensive by majority of the respondents. Similar results were reported by Thomas (2015) reported that Indian parent spent more money from their pockets in order to get decent education for their children.

Utilization of different services in form of contact with extension specialist, access to institution, satisfaction with the information received and banking personal depend on exposure of farm families to these institutions for getting information time to time as these facilities increase the knowledge for adaptation of new technologies. It was reported in the study that in both the districts Ambala and Yamunanagar more than half of the respondents $(52.00 \%$ and $67.33 \%$ ) had sometimes access to institutions respectively.

It was also reported that respondents majority of had never contacted to HAU scientists, agricultural/ extension officials, loan officials, bank officials and local officials.

The present study are in accordance with the findings of Devi (2011) who reported that the respondents were not using services of contact farmers, banks, universities, government agencies and district extension specialist. Oluwasusi (2014) also reported that 54.50 per cent of the respondents had poor contact with extension services.
It was concluded from the investigation that majority of the families had not received any sort of professional preparing was had less customary aptitude and great word related information. As to capital of farm family's mass of the family had in any event two financially dynamic individuals in their family and no relatives moved to other spot to acquire livelihood.

The respondents were having medium mindfulness about government plans. Along these lines, its need to make the mindfulness among the provincial rancher with respect to the training, bestowing aptitudes and the advantages of the administration plans.

\section{References}

Chand, R., Lakshmi Prasanna and Aruna Singh, 2011, "Farm size and productivity: Understanding the strengths of smallholders and improving their livelihoods", Economic and Political Weekly,46: 2627.

Gautam, U. S., Paliwal, D. K. and Naberia, S. 2007. Improvement in Livelihood Security for Small and Marginal Farmers through Front Line Demonstrations on Oilseed and Pulse Crops in Central India, Indian Research. Journal of Extension Education. 7 (1),1-5

Hunter, M., Dickinson, t., Nawrotzki, R. 2012. Rural livelihoods and access to natural capital: Differences between migrants and non-migrants in Madagascar. Indian Research Journal of Extension Education, 201, 15-18,

Maxwell, S. and T. Frankenberger. 1992 Household Food Security: Concepts, Indicators and Measurements: A Technical Review. New York and Rome: UNICEF and IFAD.

Raman Jodha and Manju Dahiya. 2018. 
Livelihood Problems of Small and Marginal Farm Families in Rural Areas of Haryana State. International Journal of Current. Microbiology and Applied Sciences, 7(01): 1624-1629.

Ramchandani, R. and Karmarkar, P. (2014). Sustainable Rural Livelihood Security in the Backward Districts of Maharashtra. Procedia - Social and Behavioral Sciences, 133, pp.265-278.

Sharma, L. 2011, Kissan credit card scheme: An Analysis since inception, Southern Economist, 49(20): 5-7.

Jodha R. 2018. Livelihood Security of Small and Marginal Farm Families in Gurgaon Division of Haryana State $\mathrm{Ph}$. D. Thesis, CCS Haryana Agricultural University, Hisar.

Adekoya EA. 2009. Food security and coping strategies among rural households in Oyo state, Nigeria. Journal of Food, Agriculture \& Environment, 3(3,4):457-460.

Rani P. 2015. Assessment of nutritional status of rural school going children (10-12 years) of Fatehabad district, M.Sc, theiss, CCS Haryana Agricultural University, Hisar.

Shakti Dubey RP and Sheikhy S. 2013. Assessment of food consumption pattern and nutritional status of school going children of Faizabad dDistrict, Trends in Bioscience, 6(6):755-757.

Sati V and Dahiya S. 2012. Nutritional Assessment of Rural School-Going Children (7-9 Years) of Hisar District, Haryana Open Access Scientific Reports, http://dx.doi.org/10.4172/ scientiftcreports.363.

Hens H. (2014). Assessment of nutritional status of rural school going children (7-9 years) of Gurgaon district of Haryana. M.Sc. Thesis, CCS Haryana Agricultural University, Hisar.

AMEU (Appraisal Monitoring and Evaluation Unit) (2016). Food security situation and Livelihood Communities in North Jordan assessment report.

Neha. 2011. Nutritional status of rural vs urban school going children consuming mid day meal: A comparative study. M.Sc Thesis, CCS Horyona Agricultural University, Hisar.

Rout N. 2009. Food consumption pattern and nutritional status of women in Orissa: A rural urban differential. Journal of Human Ecology, 25(3):179-185

Bal R. 2015. Socio-Economic Status and Livelihood Security of Rural Women in Punjab. Ph.D. Thesis. Punjab School of Economics Guru Nanak Dev University, Amritsar

Kharadi V, Sabapara G, Fulsoundar AB. 2015. Existing housing management practices followed by rural dairy animal owners in Surat district of Gujarat. International Journal of Farm Sciences 5(4): 299-308.

Ramaraju, 2013. Impact of total sanitation campaign on rural households in Andhra Pradesh: A case study of Vasadi village in Vizianagaram district, $\mathrm{PhD}$ Thesis, Dept. of Economics, Andhra University

Census, (2011). government of India. http://www.census India. Gov. in/2011 census/hlo-highlights. Html

Preeti. 2014. Feasibility of value added products of pearl millet as an enterprise for rural women. M.Sc Thesis, CCS Haryana Agricultural University, Hisar.

Yadav R. (2016). Acceptability of technical knowledge on cotton cultivation through media in Haryana. Ph.D Thesis, CCS Haryana Agricultural University, Hisar.

Dev M. 2012. "Small farmers in India: Challenges and opportunities", Indira Gandhi Institute of Development Research, Mumbai. Paper presented at 
"Emerging Economies Research Dialogue' Beijing, China, 14-15 November 2011 organized by ICRIER. Oluwasusi JO. 2014. Effectiveness of
Extension Services among food crop famers in Ekiti state, Nigeria, Journal of Agriculture and Food Information, 15:324-341.

\section{How to cite this article:}

Saurabh Arya, Asha Batra and Arpit Arya. 2019. Livelihood Security of Small and Marginal Farmers in Ambala Division of Haryana State, India. Int.J.Curr.Microbiol.App.Sci. 8(10): 501511. doi: https://doi.org/10.20546/ijcmas.2019.810.055 